\title{
Assessing Water Quality by Statistical Methods
}

\author{
Alina Bărbulescu 1,*(D) and Cristian Ștefan Dumitriu 2,* \\ 1 Department of Civil Engineering, Transilvania University of Brașov, 5 Turnului Street, \\ 900152 Brașov, Romania \\ 2 S.C. Utilnavorep S.A., 55 Aurel Vlaicu Avenue, 900055 Constanța, Romania \\ * Correspondence: alina.barbulescu@unitbv.ro (A.B.); cris.dum.stef@gmail.com (C.S..D.)
}

Citation: Bărbulescu, A.; Dumitriu, C.S. Assessing Water Quality by Statistical Methods. Water 2021, 13, 1026. https://doi.org/10.3390/ w13081026

Received: 5 April 2021

Accepted: 7 April 2021

Published: 9 April 2021

Publisher's Note: MDPI stays neutral with regard to jurisdictional claims in published maps and institutional affiliations.

Copyright: (c) 2021 by the authors. Licensee MDPI, Basel, Switzerland. This article is an open access article distributed under the terms and conditions of the Creative Commons Attribution (CC BY) license (https:/ / creativecommons.org/licenses/by/ $4.0 /)$.
Water is one of the natural resources most affected by anthropogenic activities, like industry, agriculture, and traffic. Moreover, pollutants resulting from different sources are reaching water bodies with insufficient or without proper treatment. Climate change impacts the water quality as well, reducing the quantities of drinking water. Apart from human health, profoundly affected by water pollution, organisms living in the water and many ecosystems are affected more and more. Considering the difficult access to the drinking water of the population from different parts of the world, preserving the water resources, assessing their quality, and taking measures for the remediation of the water bodies' natural properties is a must.

In this context, the Special Issue with the title "Assessing Water Quality by Statistical Methods" addressed topics related to groundwater vulnerability [1-4], estimating water quality parameters in natural and artificial lakes and gulfs [5-7], investigating the causes of Rivers pollution [8-10], and proposing new tools for estimating the regional extent [11] and mitigating the effects of high precipitations on the water quality [12].

The single review [1] published in this volume addresses the groundwater vulnerability evaluation by the DRASTIC method and DRASTIC-like approaches, without including the particular case of the karst aquifer. Since its proposal, DRASTIC has become an essential tool for assessing the groundwater vulnerability, being adapted to different cases, like lithology, regions, land-uses, pollutants, land cover, and types of human settlements (rural and urban). The review is based on 128 articles, giving a detailed image of the previous work and opening possible study directions.

The article of Baena-Ruiz and Pulido-Velazquez [2] adapts the DRASTIC index to obtain reliable assessments in carbonate aquifers while maintaining its original conceptual formulation. The authors combine spatial statistics and decision trees to establish the DRASTIC parameters' domains and their associated weights. Comparisons of the new method's results with those obtained using the COP for the karst aquifer [13] show a concordance on $75 \%$ of the study area, the Upper Guadiana Basin. Given its good output, this approach should be validated in future studies.

In the same idea of evaluating the groundwater quality, in another part of the worldthe United Arab Emirates - the article [3] proposes a combined approach involving a multivariate statistical analysis and water quality indices' use. The study relies on a database containing 42 concentration series of 19 water parameters collected in the Liwa area. Since the hypothesis that the series of water parameters recorded at different locations are similar was rejected, the samples were grouped in clusters and the main parameters that determined the differences between the clusters were determined by Principal Component Analysis (PCA). Finally, a quality index for assessing the water suitability for drinking was computed in two scenarios. The authors emphasized the necessity of using more than one technique to evaluate water quality for different purposes and to cross-validate the results [3].

Du et al. [4] employed the Factorial Analysis (FA) and Correspondence Analysis (CA), combined with geospatial tools, to identify the sources of inorganic nitrogen compounds 
in shallow groundwater, to determine the governing influencing factors and analyze the formation process in an agricultural area in Northeast China [4].

In the article [5], the authors investigated the long-term time series of salinity and water level of Techirghiol Lake (Romania), renowned in Europe for its sapropelic mud's therapeutic properties. These variables trends have been studied as functions of the precipitation, overland flow, groundwater recharge, and the hydraulic works from the lake's neighborhood. The study shows that the Techirghiol Lake is a heavily modified water body.

Mamun et al. [6] realized a comprehensive spatial and temporal analysis of the water quality of the Paldang reservoir (Korea), which is an important source of freshwater. The tools utilized to carry out the research were the PCA, FA, and stepwise spatial discriminant analysis (DA), together with the Trophic State Index (TSI) and Trophic State Index deviation (TSID). They show that anthropogenic activity is mainly responsible for the significant spatial variations of most water parameters. The water parameters that significantly vary during different seasons are the temperature, the biological oxygen demand, and total suspended solids. The water parameters that significantly vary at different sites are the water temperature, the electrical conductivity, the total nitrogen, the ratio biological oxygen demand: chemical oxygen demand, and total nitrogen: total phosphorus.

In their research, Al-Taani et al. [7] investigated the water quality of the Aqaba Gulf in Jordan, a zone with high touristic potential. The investigation of 19 parameters of water samples collected in different parts of the Littoral did not present specific patterns, except for the metal contents that showed increasing values close to an industrial complex by comparison to other sampling places.

The article Characteristics and Causes of Long-Term Water Quality Variation in Lixiahe Abdominal Area, China [8] presents the results of a set of statistical tests (the Mann-Kendall trend test and Sen's slope estimator) and the analysis of the correlation between the water quality variation, the water level, and the water diversion employing the cross wavelet transform and wavelet coherence. The results show that the comprehensive water quality index (CWQI) included periodic fluctuations on multiple scales from 0.25 to 5 years [8].

Yu et al. [9] analyzed twenty water parameters from samples collected during March, May, July, September, and November 2010 in Chaobai River (China). They found that the eutrophication level was severe in most locations where the water was collected, and the water was not appropriate for irrigation water (indicated by the sodium adsorption ratio). Cluster analysis was used to determine the significant spatial and temporal variation among different data series. The Gibbs plot indicated that the water-rock interaction mainly controls the water chemistry, whereas the PCA showed that river water had undergone the minerals dissolution.

Kim et al. [10] study the land-cover influence on the streams water quality in urban zones from South Korea. After classifying the watersheds in three clusters, the factorial analysis is used to select the water parameters that participate in the computation of a newly defined water quality indicator (WQImin), further employed to estimate the degree of water contamination. WQImin appears as a competitor for the other water quality indexes already known.

Costache et al. [11] introduced an integrated framework for detecting the areas prone to flooding generated by flash-floods in small river catchments as an indicator for water quality. Three models were generated in the first stage, by a combination of frequency ratio (FR), weights of evidence (WOE), and statistical index (SI), with fuzzy analytical hierarchy process (FAHP), and the best one (FAHP-WOE) was selected. In the next stage, the first step's output was weighted using the flow accumulation method to determine the valleys with different levels of susceptibility to flood. Finally, ten flood conditioning factors were used to determine flood susceptibility through the analytical hierarchy process model. Given that the higher the susceptibility to flooding is, the higher the pollution with different sediments and other materials carried by the water is, this method provides an interesting tool for pollution warning in small river catchments. 
The article [12] proposes a new evolutionary approach for determining an optimal parameter in the Inverse Distance Weighting Interpolation (IDW) method that has a large applicability in the spatial interpolation of regional data series. Proposed for the scenario, the algorithm was tested on 41 series collected at ten locations, in Dobrogea, Romania. In terms of the mean absolute error (MAE) and the mean standard error (MSE) the new algorithm outperformed the classical IDW, the ordinary kriging, and the Particle Swarm Optimization of IDW. The algorithm should be validated on other data sets.

Author Contributions: Conceptualization, A.B. and C.Ș.D.; methodology, A.B. and C.Ș.D.; formal analysis, C.S.D.; writing-A.B. and C.S.D.; writing-review and editing, A.B.; supervision, A.B.; project administration, A.B. All authors have read and agreed to the published version of the manuscript.

Funding: This research received no external funding.

Conflicts of Interest: The authors declare no conflict of interest.

\section{References}

1. Bărbulescu, A. Assessing the groundwater vulnerability: DRASTIC method and its versions: A review. Water 2020, 12, 1356. [CrossRef]

2. Baena-Ruiz, L.; Pulido-Velazquez, D. A Novel Approach to Harmonize Vulnerability Assessment in Carbonate and Detrital Aquifers at Basin Scale. Water 2020, 12, 2971. [CrossRef]

3. Bărbulescu, A.; Nazzal, Y.; Howari, F. Assessing the groundwater quality in the Liwa area, the United Arab Emirates. Water 2020, 12, 2816. [CrossRef]

4. Du, X.; Feng, J.; Fang, M.; Ye, X. Sources, Influencing Factors, and Pollution Process of Inorganic Nitrogen in Shallow Groundwater of a Typical Agricultural Area in Northeast China. Water 2020, 12, 3292. [CrossRef]

5. Maftei, C.; Buta, C.; Carazeanu Popovici, I. The Impact of Human Interventions and Changes in Climate on the Hydro-Chemical Composition of Techirghiol Lake (Romania). Water 2020, 12, 2261. [CrossRef]

6. Mamun, M.; Kim, J.Y.; An, K.-G. Multivariate Statistical Analysis of Water Quality and Trophic State in an Artificial Dam Reservoir. Water 2021, 13, 186. [CrossRef]

7. Al-Taani, A.A.; Rashdan, M.; Nazzal, Y.; Howari, F.; Iqbal, J.; Al-Rawabdeh, A.; Al Bsoul, A.; Khashashneh, S. Evaluation of the Gulf of Aqaba Coastal Water, Jordan. Water 2020, 12, 2125. [CrossRef]

8. Jiang, C.; Zhou, J.; Wang, J.; Fu, G.; Zhou, J. Characteristics and Causes of Long-Term Water Quality Variation in Lixiahe Abdominal Area, China. Water 2020, 12, 1694. [CrossRef]

9. Yu, Y.; Song, X.; Zhang, Y.; Zheng, F. Assessment of Water Quality Using Chemometrics and Multivariate Statistics: A Case Study in Chaobai River Replenished by Reclaimed Water, North China. Water 2020, 12, 2551. [CrossRef]

10. Kim, T.; Kim, Y.; Shin, J.; Go, B.; Cha, Y. Assessing Land-Cover Effects on Stream Water Quality in Metropolitan Areas Using the Water Quality Index. Water 2020, 12, 3294. [CrossRef]

11. Costache, R.; Bărbulescu, A.; Pham, Q.B. Integrated framework for detecting the areas prone to flooding generated by flash-floods in small river catchments-A useful indicator for water quality. Water 2021, 13, 758. [CrossRef]

12. Bărbulescu, C.; Șerban, M.-L. Indrecan, Improving spatial interpolation quality. IDW versus a genetic algorithm. Water 2021, 13, 863. [CrossRef]

13. Ravbar, N.; Goldscheider, N. Comparative application of four methods of groundwater vulnerability mapping in a Slovene karst catchment. Hydrogeol. J. 2008, 17, 725-733. [CrossRef] 